\title{
Neuroprotective Effects of Sodium Ferulate and Its Antidepressant-Like Effect Measured by Acute and Chronic Experimental Methods in Animal Models of Depression
}

\author{
Yongping Zhang ${ }^{1}$, Lijian Yu ${ }^{1}$, Yanping Wang ${ }^{1}$, Mingneng Liao ${ }^{1}$, \\ Xia Zhang ${ }^{1}$, Rundi $\mathrm{Ma}^{1}$, Xiaoyu Zhang ${ }^{1,2}$, Tingxi $\mathbf{Y u}^{1,3}$ \\ ${ }^{1}$ Key Laboratory of Marine Materia Medica, Guangdong Ocean University, Zhanjiang, China \\ ${ }^{2}$ Department of Otorhinolaryngology-Head and Neck Surgery, University of Maryland School of Medicine, \\ Baltimore, USA \\ ${ }^{3}$ Department of Surgery, Department of Pathology, University of Maryland School of Medicine and Baltimore \\ Veterans Affairs Medical Center, Baltimore, USA \\ E-mail: \{yulj,mard\}@gdou.edu.cn, yutingxi@yahoo.com \\ Received February 21, 2011; revised March 25, 2011; accepted March 28, 2011
}

\begin{abstract}
Antidepressants with novel targets and without side effects are in great demand. Ferulic acid (FA) is a ubiquitous phenolic acid of low toxicity, and sodium ferulate (SF) is its sodium salt. Our previous studies have revealed that FA and SF show significant protective effect on excitotoxicity, we now test its potential neuroprotective and antidepressant-like effects. MTT assay and morphological analysis by fluorescence microscopy were adopted to measure the neuroprotective effects of SF; forced-swimming, tail-suspension, and chronic mild stress (CMS) tests were performed to assess its antidepressant-like activity. The results showed that $\mathrm{SF}$ had protection against $\mathrm{H}_{2} \mathrm{O}_{2}$-induced oxidative damage and dexamethasone (DXM)-induced neurotoxicity pheochromocytoma (PC12) cells. Acute administration of SF markedly decreased the duration of immobility during forced-swimming in rats and mice and tail-supension tests in mice. However, SF has no any effects on reserpine-induced hypothermia, 5-hydroxytryptophan-induced head-twitch response, and potentiation of noradrenaline toxicity in mice. Chronic administration of SF reversed the effects of CMS on consumption of food and sucrose solution, weight gain, and histopathology of hippocampus by light microscopy, and potently shortened the immobility time during forced-swimming test following CMS in rats. This study provides evidence that SF possesses obviously antidepressant-like activity, and the antidepressant-like effect may result from its neuroprotective effects.
\end{abstract}

Keywords: Sodium Ferulate, Neuroprotective Effect, PC12 Cells, Animal Models of Depression

\section{Introduction}

Despite the advances in the treatment of depression with selective serotonin reuptake inhibitors (SSRIs) and serotonin and norepinephrine reuptake inhibitors (SNRIs), there continue to be many unmeet clinical needs with respect to both efficacy and side effects. To address these needs, antidepressants with novel mechanisms and targets of action and without side effects are in great demand. The increased desire to use in vitro and in vivo techniques in depression has resulted in the search for clonal cell lines and animal models which may be useful for screening antidepressant drugs and for studying the mechanism of action of antidepressant drugs.

FA, 3-(4-hydroxy-3-methoxyphenyl)-2-propenoic acid (Figure 1A), was isolated from several traditional Chinese medicines and herbs, such as Felula assafoetida L., Ligusticum chuanxiong Hort., Equisetum hiemale L., Allium cepa L., Raphanus sativus L., rice bran and other plants [1]. FA is water-insoluble, but its sodium salt, SF (Figure 1B), is water-soluble, stable, and can be prepared by chemical synthesis [2]. FA shows a lot of bio- 

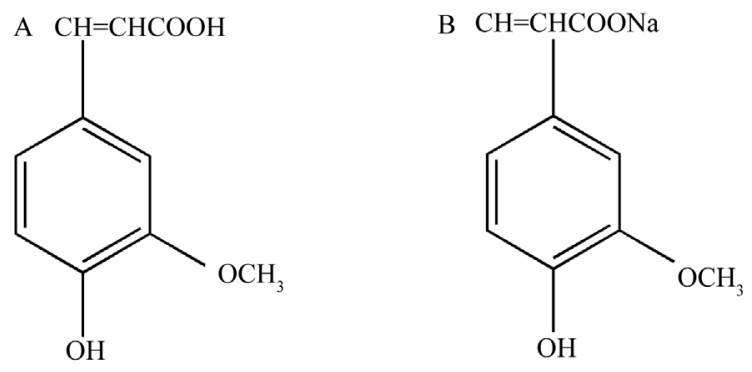

Figure 1. Chemical structure of ferulic acid (A) and sodium ferulate (B).

logical activities, in cluding antioxidant $[3,4]$, anti-inflammatory [5,6], and hypotensive effect $[7,8]$. Chinese scientists have contributed a lot to its investigation, and as an available blood-activating and stasis-eliminating component, it has been extensively applied to the treatment of vascular diseases of heart and brain, and obtained excellent efficiency in China [9].

Long-term administration of FA induces resistance to beta-amyloid peptide toxicity in the brain, suggesting that FA may be a useful chemopreventive agent against Alzheimer's disease [10]. FA have sedative effect [11], and the plants containing FA were employed, for instance, in the treatment of headache and irritability, apoplexy, stasis, and etc. $[12,13]$. FA is a metabolite of 5-caffeoylquinic acid found abundantly in coffee [7], this origin may be evoked the relationships between coffee and depression considered. Our previous work demonstrates that the maternal ig excessive administration of monosodium glutamate (MSG) at a late stage of pregnancy results in a series of behavioral disturbance, including MSG-induced hyperactivity that is reminiscent of what is seen in the children suffered from attention deficit hyperactivity disorder, and obvious histopathological lesion in hippocampus in the filial mice [14], and the administration of SF not only has no obvious effects on behavior and histopathology, but also reverses the effects of MSG on them [15]. The results suggest that $\mathrm{SF}$ is a novel competitive N-methyl-D-aspartate (NMDA) receptor antagonist and neuroprotective agent. Since administration of SF has potent protective effects against Glu-induced neurotoxicity in adult mice [16], it is interesting to further investigate the neuroprotective effects of SF and antidepressant-like effects of SF.

\section{Materials and Methods}

\subsection{Drugs and Chemical}

SF was purchased from Yaoyou Pharmaceutic Co. Ltd (Chongqing, China), and fluoxetine (FLU) hydrochloride purchased from Eli Lilly and Company Limited (USA).
Dexamethasone (DXM) sodium phosphate was purchased from Xinzheng Pharmaceutic Co. Ltd (Tianjin, China); $\mathrm{H}_{2} \mathrm{O}_{2}$ purchased from Guangzhou Chemical Factory (China). Dulbecco's Modified Eagle Medium (DMEM), 3-(4,5-dimethylthiazol-2-yl)-2,5-diphenyltetrazolium bromide (MTT), Triton X-100, and sodium dodecyl sulfate (SDS) were purchased from Sigma Chemical Co.; and newborn calf serum (NCS) obtained from Sijiqing Biological Material Co. (Hangzhou, China). All other chemicals used were of reagent grade.

\subsection{Cell Line and Cell Culture}

A clonal cell line derived from a pheochromocytoma of the rat adrenal medulla [17] was purchased from Shanghai Institute of Biochemistry and Cell Biology, Chinese Academy of Sciences. Cells were grown in DMEM supplemented with $10 \%$ NCS, $5 \%$ horse serum and antibiotics (100 units $/ \mathrm{ml}$ penicillin, $100 \mu \mathrm{g} / \mathrm{ml}$ streptomycin) in flasks precoated with collagen [18]. The culture was replaced after 2 months of passage by thawing a fresh aliquot of frozen cells. The culture were maintained in a humidified atmosphere containing $5 \% \mathrm{CO}_{2}$ at $37^{\circ} \mathrm{C}$. Cells in log phase growth were used in the experiments.

\subsection{Animal}

Adult male Sprague-Dawley (SD) strain rats weighing $220-280 \mathrm{~g}$ and Kunming (KM) mice weighing $23-26 \mathrm{~g}$ (specific pathogen free) purchased from the experimental animal center of Guangdong Medical College (experimental experimental animal license SCXKyue 20072008A034, No.0001909; Zhanjiang, China), were used across all the experiments. They had free access to tap water and standard laboratory food unless otherwise stated. Housing conditions were controlled, temperature was maintained at $22^{\circ} \mathrm{C} \pm 1{ }^{\circ} \mathrm{C}$ with approximately $60 \%$ relative humidity. They were kept on a reversed 12/12 h light/dark cycle (light 07:00 - 19:00 h). Animals were acclimated to the animal quarters for 1 week (for rats) or 3 days (for mice) before any experimental procedure. All the animals were treated in compliance with "Guidance Suggestion for the Care and Use of Laboratory Animals" issued by The Ministry of Science and Technology of People's Republic of China.

\subsection{MTT Assay}

The mitochondrial metabolism of MTT to its insoluble blue formazan was used for enumerating cells to assess the effects of $\mathrm{H}_{2} \mathrm{O}_{2}$, and DXM on the growth of PC12 cells and the protective effects of SF against oxidative damage and glucocorticoid-induced neurotoxicity ac- 
cording to the methods of Hansen et al. [19]. Briefly, single-cell suspensions were prepared and seeded into 96 well microculture plates with $1.0 \times 10^{5}$ cells $/ \mathrm{ml}(90$ $\mu \mathrm{l} /$ well). Cells were cultured for $12 \mathrm{~h}$ before addition of drugs. Drugs were diluted into DMEM and added to each well in a volume of $10 \mu \mathrm{l}$. Cells were incubated at $37^{\circ} \mathrm{C}$ for the time indicated. MTT solution $(5 \mathrm{mg} / \mathrm{ml})$ was aliquoted to each well in a volume of $20 \mu \mathrm{l}$, and $5 \mathrm{~h}$ later $100 \mu \mathrm{l}$ of the solubilization solution (10\% SDS- $5 \%$ isobutyl alcohol-0.012 $\mathrm{M} \mathrm{HCl}(\mathrm{w} / \mathrm{v} / \mathrm{v}))$ was added into each well. The plates were allowed to stand overnight in the incubator in a humidified atmosphere. Absorbance at 570 $\mathrm{nm}$ was determined for each well using an ELISA reader. Control wells contained all of the agents presented in the treated wells except the drug (s). Each experimental point was performed in three replicates. Data were expressed as a percentage of untreated control cultures.

\subsection{Effect of SF on $\mathrm{H}_{2} \mathrm{O}_{2}$-Induced PC12 Cell Damage}

\subsubsection{Cell Viability Assay}

The indicated concentration of SF was added $1 \mathrm{~h}$ prior to $\mathrm{H}_{2} \mathrm{O}_{2}(150 \mu \mathrm{M})$ stimulation. Following 24-h incubation, the viability of cells treated with or without $\mathrm{H}_{2} \mathrm{O}_{2}$ or $\mathrm{SF}+$ $\mathrm{H}_{2} \mathrm{O}_{2}$ was evaluated by assessing the reduction of MTT.

\subsubsection{Morphological Analysis by Fluorescence Microscopy}

Cells were incubated in the presence of SF $(40 \mu \mathrm{M})$ for 1 $\mathrm{h}$, and $100 \mu \mathrm{M} \mathrm{H}_{2} \mathrm{O}_{2}$ for additional incubation of $24 \mathrm{~h}$. $\mathrm{H}_{2} \mathrm{O}_{2}$-induced cell apoptosis was analyzed by acridine orange/ethidium (AO/EB) (Sino-American Biotechnology Co.) double fluorescent staining. Cells were washed with phosphate buffered saline (PBS), rinsed in PBS, and then AO/EB solution (one part of $100 \mu \mathrm{g} / \mathrm{ml}$ AO in PBS, one part of $100 \mu \mathrm{g} / \mathrm{ml} \mathrm{EB}$ in PBS) was added [20]. Cells were analyzed in a fluorescence microscope (DMIRB, Leica) using a fluorescein filter.

\subsection{Effect of SF on DXM-Induced PC12 Cell Damage}

The indicated concentration of SF was added $1 \mathrm{~h}$ prior to DXM $(200 \mu \mathrm{M})$. Following 24-h incubation, the viability of cells treated with or without DXM or SF + DXM was evaluated by assessing the reduction of MTT.

\subsection{Forced-Swimming Test}

Measurement of immobility time was carried out by observing the motoric activity of the mice or rats, which were placed in a pool of water. A glass cylinder, $15 \mathrm{~cm}$ (for mice) or $30 \mathrm{~cm}$ (for rats) in diameter, height $20 \mathrm{~cm}$ (for mice) or $40 \mathrm{~cm}$ (for rats), was filled with water to a height of $12 \mathrm{~cm}$ (for mice) or $24 \mathrm{~cm}$ (for rats). The temperature of water was $25^{\circ} \mathrm{C} \pm 1{ }^{\circ} \mathrm{C}$. Each mouse or rat received twice a respective dose of FLU $(20 \mathrm{mg} / \mathrm{kg}$, ig) or SF $(20 \mathrm{mg} / \mathrm{kg}, 40 \mathrm{mg} / \mathrm{kg}, 80 \mathrm{mg} / \mathrm{kg}$, ip) $17 \mathrm{~h}$ and $7 \mathrm{~h}$ (for FLU) or 7 minutes (for SF) before the forcedswimming test. This dose of FLU was chosen because it had been shown to be differentially effective in HR vs. LR animals [21]. The mice or rats in controls received ip injection of physiological saline instead of SF. And then the animals were subjected to the test. Measurement was carried out for six (for mice) or five minutes (for rats). For mice, the first two minutes the animal was allowed to adjust to the new conditions; after these two minutes, the immobility time that alternated with conditions of enhanced motor activity was measured. Immobility time was measured with a stopwatch for the next four minutes [22]. For rats, no time the animal was allowed to adjust to the new conditions. Immobility time is the time during which the animal floated on the surface with front paws together and made only those movements which were necessary to keep afloat. Shorter immobility time is an indicator of the stronger antidepressant effect of the tested substance [22-25].

\subsection{Tail-Suspension Test}

Each mouse received twice a respective dose of FLU (20 $\mathrm{mg} / \mathrm{kg}$, ig) or SF (20 mg/kg, $40 \mathrm{mg} / \mathrm{kg}, 80 \mathrm{mg} / \mathrm{kg}$, ip) 17 $\mathrm{h}$ and $7 \mathrm{~h}$ (for FLU, ig) or 7 minutes (for SF, ip) before the tail-suspension test, the mice in control received ip injection of physiological saline instead of SF, and then the animals were subjected to the test. A cord of about 50 $\mathrm{cm}$ in length was stretched between two metal tripods at a height of ca $70 \mathrm{~cm}$, to which the mice were attached by the tail with sticky tape. After the initial period (the first two minutes) of vigorous motor activity, the mice became still and the immobility time was measured with a stopwatch for a total duration of 4 minutes [25,26]. Mice were considered immobile when they hung passively and completely motionless.

\subsection{CMS Procedures}

The animals were assigned randomly into six matched groups $(\mathrm{n}=11$ animals in each group) based on weight, sucrose consumption ( $1 \%$ sucrose solution), and locomotor behavior in an open field test before onset of CMS: control, CMS, positive control (CMS + FLU), CMS + SF $(20 \mathrm{mg} / \mathrm{kg} / \mathrm{d}, 40 \mathrm{mg} / \mathrm{kg} / \mathrm{d}, 80 \mathrm{mg} / \mathrm{kg} / \mathrm{d})$ groups. The stressed rats were exposed to CMS for 28 days; The rats in CMS + FLU group were exposed to CMS and received administration of FLU $(2.0 \mathrm{mg} / \mathrm{kg} / \mathrm{d}$, ig, 
once-daily) for 28 days; The rats in CMS + SF groups were exposed to CMS and received administration of SF (20 mg/kg/d, $40 \mathrm{mg} / \mathrm{kg} / \mathrm{d}, 80 \mathrm{mg} / \mathrm{kg} / \mathrm{d}$, ip, once-daily) respectively for 28 days. The control rats were given ordinary daily care and received ip administration of normal saline simultaneously for 28 days. The stressed and control rats were kept in different rooms to allow independent manipulation of their environments during the duration of the stress procedure. Control rats were housed together, while the stressed rats were housed singly.

Most of the stressors were adapted from the procedure described by Willner and collaborators [27] and some stressors were included from Moreau and collaborators (e.g. empty water bottle, restricted food) [28]. Each week included $2 \mathrm{~h}$ of paired caging, $3 \mathrm{~h}$ of tilted cage (45 degrees), $18 \mathrm{~h}$ of food deprivation immediately followed by $1 \mathrm{~h}$ of restricted access to food ( 5 micropellets), $2 \times 18 \mathrm{~h}$ of water deprivation immediately followed by $1 \mathrm{~h}$ exposure to an empty bottle, $21 \mathrm{~h}$ of wet cage $(200 \mathrm{ml}$ water in $100 \mathrm{~g}$ sawdust bedding), and $36 \mathrm{~h}$ of continuous light. Stressors were presented both during the rats' active (dark) period and during the inactive (light) period. The same stressors were used in all experiments.

\subsubsection{Food and Fluid Consumption, Sucrose Intake and Body Weight}

Food and fluid consumption, sucrose intake ( $1 \%$ sucrose solution) and body weight were measured once a week. During a one-hour window after 23 hours of food and water deprivation, the fluid consumption and sucrose intake were measured by comparing bottle weight before and after the one-hour window, and expressed in relation to the animal's body weight $(\mathrm{ml} / \mathrm{kg})$. Baseline was measured five days before the start of CMS. The food and water deprivation period preceding sucrose intake measurement may be considered as a further stress applied on top of the CMS protocol. However, control rats were also exposed to the food and water deprivation, as a part of the sucrose test. A percent preference for sucrose was calculated by determining the percentage of total fluid consumption accounted for by ingestion of the $1 \%$ sucrose solution.

\subsubsection{Open Field Test during CMS}

The open-field test was conducted on the same day each week (Thursday) in a quiet room. The open-field apparatus consisted of a raised plastic platform $(80 \times 80 \times 40$ $\mathrm{cm})$. The floor was marked with a grid dividing it into 25 equal-size squares. Each animal was tested in the apparatus once. It was placed in the central square and observed for $3 \mathrm{~min}$. A record was kept of the time each rat, the amount of time it spent rearing (defined as standing upright on its hind legs), and the number of grid lines it crossed with at least three paws. Between animal tests the apparatus was cleaned [29].

\subsubsection{Forced-Swimming Test Following CMS in Rats} The rats exposed to CMS and received SF or FLU for 28 days were subjected to forced-swimming, and the measurement of immobility time was carried out by observing the motoric activity of the rats as described above. The final administration of SF was given $24 \mathrm{~h}$ prior to testing.

\subsubsection{Examination of Histopathology}

The rats exposed to CMS and received SF or FLU for 28 days, 4 mice of each group were anaesthetized ip with sodium pentobarbital $(60 \mathrm{mg} / \mathrm{kg})$ and then sacrificed by perfusion fixation of the central nervous system (CNS) with $40 \mathrm{~g} / \mathrm{L}$ formaldehyde. The whole brain was excised carefully, and was further fixed in $40 \mathrm{~g} / \mathrm{L}$ formaldehyde for 1 week. The hippocampal region of each animal was sectioned, and $10-\mu \mathrm{m}$-thick sections were cut and stained with hematoxylin and eosin (HE). 4 sections cutting across hippocampal region were examined by light microscopy. A representative section was presented in results.

\subsection{Data Analyses}

Values are expressed as the means \pm SEM or means \pm SD of 11 animals per group. Data were analyzed with SPSS 10.0 software. A probability of $\mathrm{P}<0.05$ was considered significant.

\section{Results}

\subsection{Protective Effect of $\mathrm{SF}$ against $\mathrm{H}_{2} \mathrm{O}_{2}$-Induced Cytotoxicity in PC12 Cells}

To determine the effect of SF on $\mathrm{H}_{2} \mathrm{O}_{2}$-induced cytotoxicity, $\mathrm{PC} 12$ cells were pretreated with varying concentrations of SF for 1 h. $150 \mu \mathrm{M} \mathrm{H}_{2} \mathrm{O}_{2}$ was added for additional $24 \mathrm{~h}$ incubation. Cell viability then was examined using an MTT mitochondrial function assay. As shown in Figure 2, $\mathrm{H}_{2} \mathrm{O}_{2}(150 \mu \mathrm{M})$ significantly decreased cell viability, which was concentration-dependently attenuated by SF treatment.

Morphologic alanalysis of $\mathrm{H}_{2} \mathrm{O}_{2}$-induced cytotoxicity was investigated using $\mathrm{AO} / \mathrm{EB}$ staining for fuorescence microscopy. Obvious difference was observed in the number of apoptotic and necrotic cells between the $\mathrm{H}_{2} \mathrm{O}_{2}$ - and $\mathrm{SF}+\mathrm{H}_{2} \mathrm{O}_{2}$-treated groups (Figure 3B, 3C); obvious differences were also observed in the nuclei of $\mathrm{H}_{2} \mathrm{O}_{2^{-}}$, SF $+\mathrm{H}_{2} \mathrm{O}_{2}$-treated and untreated $\mathrm{PC} 12$ cells after staining with $\mathrm{AO} / \mathrm{EB}$. AO/EB dyes stained morphologically normal nuclei green (Figure 3A), whereas $100 \mu \mathrm{M}$ 


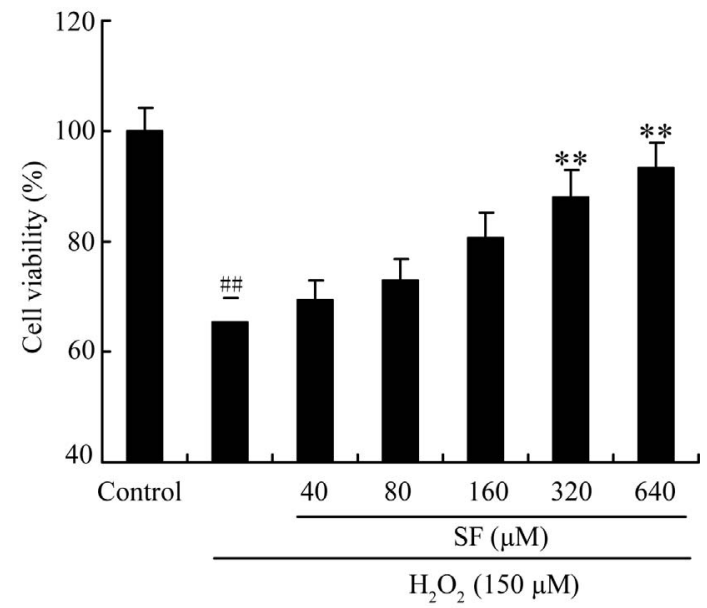

Figure 2. Protective effect of $\mathrm{SF}$ on $\mathrm{H}_{2} \mathrm{O}_{2}$-induced cytotoxicity in $\mathrm{PC} 12$ cells. The indicated concentrations of $\mathrm{SF}$ was added $1 \mathrm{~h}$ prior to $\mathrm{H}_{2} \mathrm{O}_{2}(150 \mu \mathrm{M})$ stimulation. Following 24-h in cubation, the viability of cells treated with or without $\mathrm{H}_{2} \mathrm{O}_{2}$ or $\mathrm{SF}+\mathrm{H}_{2} \mathrm{O}_{2}$ was examined by MTT assay. The data of one representative experiment from three independent experiments were expressed as mean \pm SEM $(n=$ 4). \#\# $\mathbf{P}<0.01$ as compared with control group; $* \mathbf{P}<0.05$, $* * \mathbf{P}<0.01$ as compared with $\mathrm{H}_{2} \mathrm{O}_{2}$ corticosterone group.

$\mathrm{H}_{2} \mathrm{O}_{2}$-treated cells demonstrated red or orange, smaller and shrunken nuclei (Figure 3B). These changes in nuclear morphology, which were observed after $24 \mathrm{~h}$ of 100 $\mu \mathrm{M} \mathrm{H}_{2} \mathrm{O}_{2}$ treatment, reflected chromatin condensation and nuclearshrinkage. However, in comparison with $\mathrm{H}_{2} \mathrm{O}_{2}$, PC12 cells treated with SF $(20 \mu \mathrm{M})$ and then with $\mathrm{H}_{2} \mathrm{O}_{2}(100 \mu \mathrm{M})$ demonstrated lighter yellow, and slight nuclear shrinkage (Figure 3C). The results indicated that $\mathrm{SF}$ partly protected PC cells from apoptotic induction by $\mathrm{H}_{2} \mathrm{O}_{2}$.

\subsection{Protective Effect of SF against DXM-Induced Neurotoxicity in PC12 Cells}

To determine the effect of SF on DXM-induced cytotoxicity, $\mathrm{PC} 12$ cells were pretreated with varying concentrations of SF for $1 \mathrm{~h} .200 \mu \mathrm{M}$ DXM was added for an additional $24 \mathrm{~h}$ incubation. Cell viability then was examined using an MTT mitochondrial function assay. As shown in Figure 4, DXM $(200 \mu \mathrm{M})$ significantly decreased cell viability, which was concentration-dependently attenuated by SF treatment.

\subsection{Effects of Acute Administration of SF on the Immobility Time in Forced-Swimming and Tail-Suspension Animal Models of Depression}

The results showed that acute administration of SF potently decreased the duration of immobility during

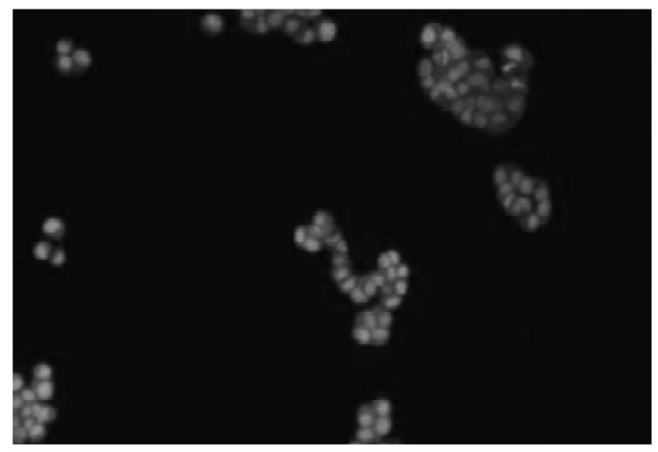

(a)

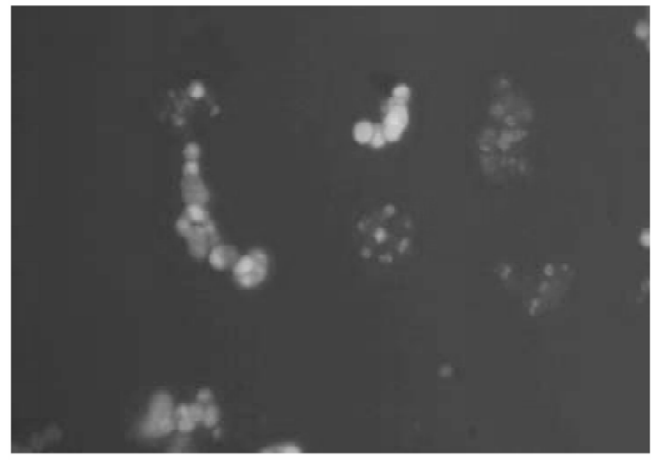

(b)

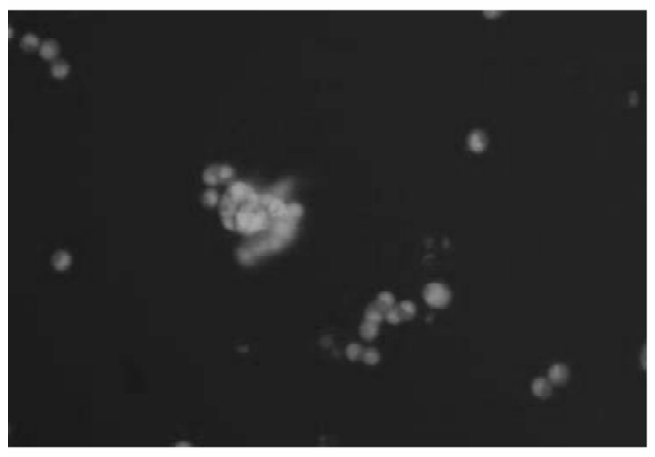

(c)

Figure 3. Protective effect of $\mathrm{SF}$ on $\mathrm{H}_{2} \mathrm{O}_{2}$-induced apoptosis in $\mathrm{PC} 12$ cells by double staining with AO/EB. PC12 cells were incubated in the presence of SF $(40 \mu M)$ for $1 \mathrm{~h}$, and $100 \mu \mathrm{M} \quad \mathrm{H}_{2} \mathrm{O}_{2}$ for additional incubation of $24 \mathrm{~h}$. $\mathrm{H}_{2} \mathrm{O}_{2}$-induced cell apoptosis was analyzed by $\mathrm{AO} / \mathrm{EB}$ double fluorescent staining as described in "Materials and methods". Cells in which nuclei were red or orange (yellow-red) indicate apoptotic cells (original magnification, $\times 200$ ). $a$. control; b. $\mathrm{H}_{2} \mathrm{O}_{2}(100 \mu M)$; c. SF $(20 \mu M)+\mathrm{H}_{2} \mathrm{O}_{2}(100 \mu M)$.

forced-swimming in mice and rats $(\mathrm{P}<0.05)$ (Table 1, 2) and tail-supension $(\mathrm{P}<0.01)$ tests in mice (Table 3), suggesting that SF has the acute antidepressant-like effect.

It shoud be noted that rat is more sensitive to SF than mouse is, because SF $(20 \mathrm{mg} / \mathrm{kg})$ significantly decreased the duration of immobility in rat, but the same amount of $\mathrm{SF}$ was not effective in mice. 


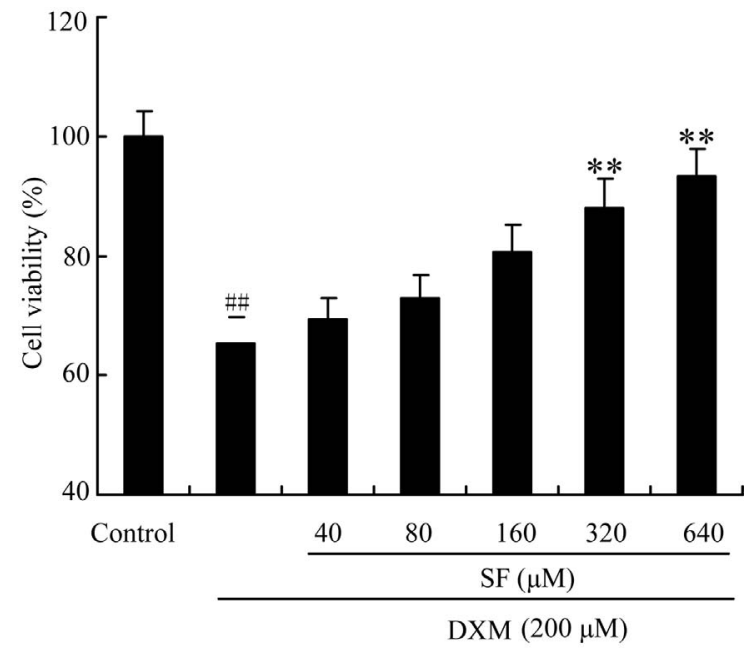

Figure 4. Protective effect of SF against DXM-induced neurotoxicity in PC12 cells. The indicated concentrations of SF were added $1 \mathrm{~h}$ prior to DXM $(200 \mu \mathrm{M})$. Following 24-h incubation, the viability of cells treated with or without DXM or SF + DXM was evaluated by assessing the reduction of MTT. The data of one representative experiment from three independent experiments were expressed as mean $\pm \operatorname{SEM}(n=4)$. \#\# $P<0.01$ as compared with control group; *P $<0.05, * * P<0.01$ as compared with $D X M$ group.

Table 1. Effect of acute ip administration of SF on the immobility time during forced-swimming test in mice.

\begin{tabular}{cccc}
\hline Ggroups & $\begin{array}{c}\text { Dose } \\
(\mathrm{mg} / \mathrm{kg})\end{array}$ & $\begin{array}{c}\text { Immobility time }(\mathrm{s}) \\
(\bar{x} \pm S D)\end{array}$ & Change (\%) \\
\hline Control & 0 & $164.8 \pm 28.7$ & - \\
FLU & $20 \times 2$ & $123.5 \pm 30.4^{*}$ & -25.1 \\
SF & $20 \times 2$ & $142.6 \pm 29.6$ & -13.5 \\
& $40 \times 2$ & $117.3 \pm 21.5^{*}$ & -28.8 \\
& $80 \times 2$ & $112.4 \pm 24.9^{*}$ & -31.8 \\
\hline
\end{tabular}

$* \mathrm{P}<0.05$ Student's t-test $(\mathrm{n}=10)$ versus control.

Table 2. Effect of acute ip administration of SF on the immobility time during forced-swimming test in rats.

\begin{tabular}{cccc}
\hline Ggroups & $\begin{array}{c}\text { Dose } \\
(\mathrm{mg} / \mathrm{kg})\end{array}$ & $\begin{array}{c}\text { Immobility time }(\mathrm{s}) \\
(\bar{x} \pm S D)\end{array}$ & Change $(\%)$ \\
\hline Control & 0 & $152.5 \pm 28.2$ & - \\
FLU & $20 \times 2$ & $109.8 \pm 30.8^{*}$ & -33.4 \\
SF & $20 \times 2$ & $103.4 \pm 41.2^{*}$ & -9.7 \\
& $40 \times 2$ & $108.5 \pm 48.32^{*}$ & -35.6 \\
& $80 \times 2$ & $125.9 \pm 53.5$ & -39.7 \\
\hline
\end{tabular}

$* \mathrm{P}<0.05$ Student's t-test $(\mathrm{n}=8)$ versus control.

Table 3. Effect of acute ip administration of SF on the immobility time during tail-suspension test in mice.

\begin{tabular}{cccc}
\hline Ggroups & $\begin{array}{c}\text { Dose } \\
(\mathrm{mg} / \mathrm{kg})\end{array}$ & $\begin{array}{c}\text { Immobility time }(\mathrm{s}) \\
(\bar{x} \pm S D)\end{array}$ & Change (\%) \\
\hline Control & 0 & $168.2 \pm 22.6$ & - \\
FLU & $20 \times 2$ & $112.1 \pm 39.4^{* *}$ & -28.0 \\
SF & $20 \times 2$ & $151.9 \pm 32.3$ & -32.2 \\
& $40 \times 2$ & $108.3 \pm 40.7^{* *}$ & -28.9 \\
& $80 \times 2$ & $101.5 \pm 23.8^{* *}$ & -17.4 \\
\hline
\end{tabular}

$* * \mathrm{P}<0.01$ Student's t-test $(\mathrm{n}=10)$ versus control.

\subsection{Effects of Chronic Administration of SF on CMS Animal Model of Depression}

\subsubsection{Food Consumption and Body Weight Gain}

The mean food consumption and body weight of rats in the six experimental groups did not differ significantly initially. Over the four weeks of the experiment, the mean body weight increased in the six groups. Compared to the control animals, the weight gain was significantly less in the group exposed to CMS ( $\mathrm{P}<0.05)$, but the weight gain in the CMS + SF $(20,40,80 \mathrm{mg} / \mathrm{kg} / \mathrm{d})-$ and the CMS + FLU $(2.0 \mathrm{mg} / \mathrm{kg} / \mathrm{d})$-treated rats was more than that in the group exposed to CMS. At the end of fourth week, the control rats had gained $111.1 \mathrm{~g}$, the CMS-treated rats had gained only $77.1 \mathrm{~g}$, while the CMS + SF $(20,40,80 \mathrm{mg} / \mathrm{kg} / \mathrm{d})-$ and CMS + FLU $(2.0 \mathrm{mg} / \mathrm{kg} /$ d)-treated rats had gained $83.7,92.5,88.0$ and $79.6 \mathrm{~g}$ (Figure 5), respectively. Over the four weeks of the experiment, the mean food consumption (\%) decreased in the six groups. Compared to the control animals, the food consumption was significantly less in the group exposed to CMS $(\mathrm{P}<0.01)$, but food consumption in the CMS + $\mathrm{SF}(20,40,80 \mathrm{mg} / \mathrm{kg} / \mathrm{d})-$ and the CMS + FLU $(2.0$ $\mathrm{mg} / \mathrm{kg} / \mathrm{d}$ )-treated rats was significantly more than that in the group exposed to CMS $(\mathrm{P}<0.01)$. At the end of fourth week, the control rats consumed food of $8.2 \mathrm{~g} / 100$ $\mathrm{g} / \mathrm{d}$, the CMS-treated rats consumed food of only

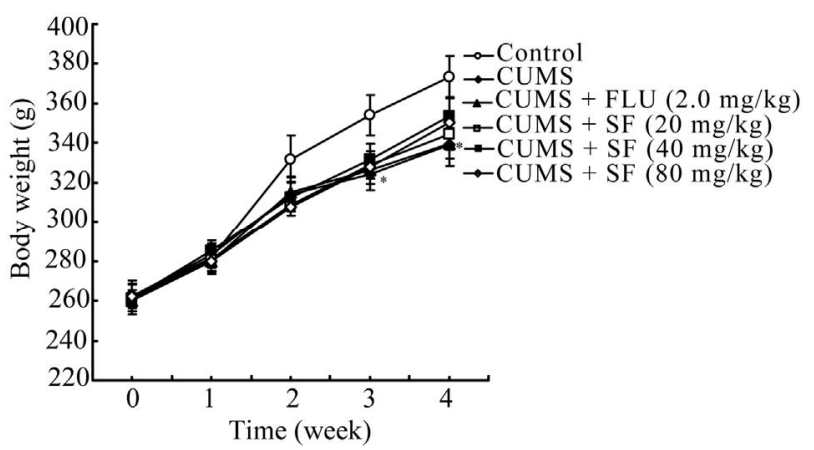

Figure 5. Time course of body weight gain. Data are represented as the means \pm SEM. $n=11$ animals in each group; *P $<0.05$ vs. control; Control ( $(\circ)$, CMS ( $\diamond)$, CMS + FLU $(\triangle)$, CMS + SF (20 mg/kg) (口), CMS + SF (40 mg/kg) (घ) and CMS + SF $(80 \mathrm{mg} / \mathrm{kg})(\diamond)$.

$6.3 \mathrm{~g} / 100 \mathrm{~g} / \mathrm{d}$, while the CMS + SF $(20,40,80 \mathrm{mg} / \mathrm{kg} / \mathrm{d})-$ and $\mathrm{CMS}+\mathrm{FLU}(2.0 \mathrm{mg} / \mathrm{kg} / \mathrm{d})$-treated rats consumed food of 7.0, 7.2, 7.2 and $7.1 \mathrm{~g} / 100 \mathrm{~g} / \mathrm{d}$ (Figure 6), respectively.

\subsubsection{Consumption of Sucrose Solution}

The stressed animals consumed significantly less sucrose solution by the end of the second week $(\mathrm{P}<0.01)$ and continued to do so at the end of the third and the fourth weeks ( $\mathrm{P}<0.01$ ) (Figure 7). However, the consumption of sucrose solution by CMS + SF $(20-80 \mathrm{mg} / \mathrm{kg} / \mathrm{d})-$ 


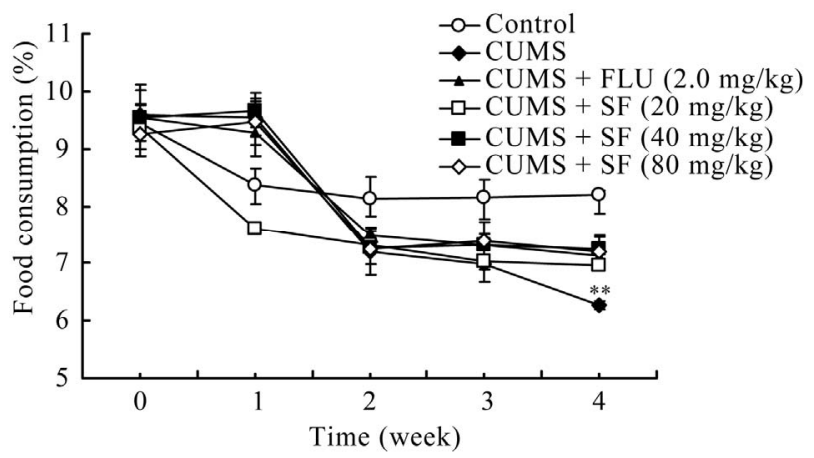

Figure 6. Time course of food consumption. Data are represented as the means \pm SEM. $n=11$ animals in each group; **P $<0.01$ vs. control; Control (०), CMS $(\diamond)$, CMS + FLU (A), CMS + SF (20 mg/kg) (ロ), CMS + SF (40 mg/kg) (घ) and CMS $+\mathrm{SF}(80 \mathrm{mg} / \mathrm{kg})(\diamond)$.

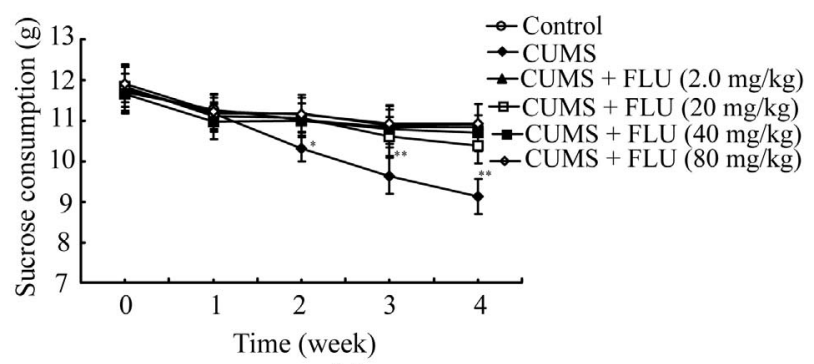

(a)

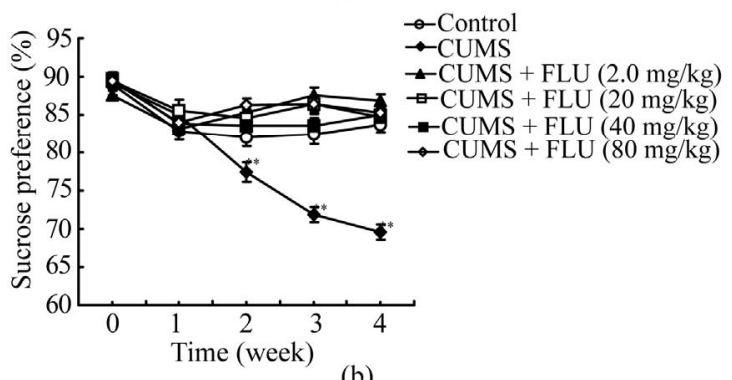

(b)

Figure 7. Time course of sucrose consumption (a), and sucrose percentage (b). Prior to each test, rats were food- and water-deprived for $23 \mathrm{~h}$. They were then exposed to both a $1 \%$ sucrose solution and tap water. Sucrose preference $=$ amount of sucrose solution consumption / total fluid consumption $\times 100 \%$. Data are represented as means \pm SEM. $n$ $=11$ animals in each group; $* \mathbf{P}<0.05, * * \mathbf{P}<0.01$ vs. control; Control $(\circ)$, CMS $(\diamond)$, CMS + FLU ( $\triangle)$, CMS + SF $(20 \mathrm{mg} / \mathrm{kg})(\square), \mathrm{CMS}+\mathrm{SF}(40 \mathrm{mg} / \mathrm{kg})(\square)$ and CMS + SF (80 $\mathrm{mg} / \mathrm{kg})(\diamond)$.

treated rats was significantly more than that by the rats exposed to CMS ( $\mathrm{P}<0.01)$, and was comparable with the control and positive control $(\mathrm{P}>0.05)$.

\subsubsection{Locomotion and Exploration Behavior}

Open field testing is used to assess locomotion, exploration, and anxiogenic-like behavior of rats. Compared to stressed rats, the control animals $(\mathrm{P}<0.01)$, the CMS +
$\mathrm{SF}(80 \mathrm{mg} / \mathrm{kg} / \mathrm{d})-$ and CMS + FLU $(2.0 \mathrm{mg} / \mathrm{kg} / \mathrm{d})$-treated rats (number of squares crossed: $\mathrm{P}<0.05$, number of rearing: $\mathrm{P}<0.01$ ) were more active in the open field (Figure 8).

\subsubsection{Immobility Time during Forced-Swimming Test Following CMS}

As shown in Figure 9, CMS potently increased the duration of immobility $(\mathrm{P}<0.05)$, and long-term administration of SF potently decreased the immobility time during forced-swimming test in rat model of depression $(\mathrm{P}<$ $0.05)$, suggesting that SF has the chronic antidepressant effect.

\subsubsection{Histopathology of Hippocampus}

The results showed CMS-induced hippocampal lesions characterized by slight intracellular edema, degeneration and hyperplasia (Figure 10B) in comparison with the control (Figure 10A). It is interesting that significant neuronal damage was not detected in the hippocampi of the rats treated with CMS + FLU or CMS + SF (Figure 10C, 10D, 10E, 10F). These findings suggest that stressinduced damage and loss of hippocampal neurons may contribute to the pathophysiology of depression, and treatment with SF overcomes the stress-induced damage and loss of hippocampal neurons.
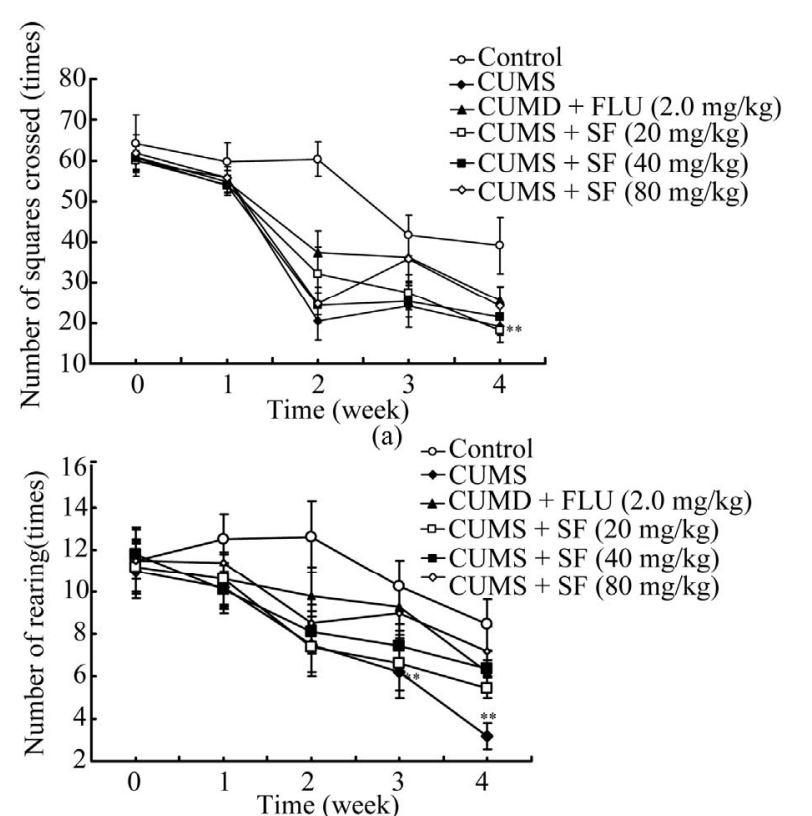

(b)

Figure 8. Time course of locomotion and exploratory behavior. Rats were placed in the central square of the open field and observed for $3 \mathrm{~min}$; Data are represented as the means \pm SEM. $\mathrm{n}=11$ animals in each group; $* \mathrm{P}<0.05, * * \mathrm{P}<0.01 ; \mathrm{a}$. Number of squares crossed (times); b. Number of rearing (times); Control (०), CMS ( $\diamond)$, CMS + FLU ( $\triangle)$, CMS + SF (20 mg/kg) ( $\square)$, CMS + SF (40 mg/kg) (a) and CMS + SF $(80 \mathrm{mg} / \mathrm{kg})(\diamond)$ rats. 


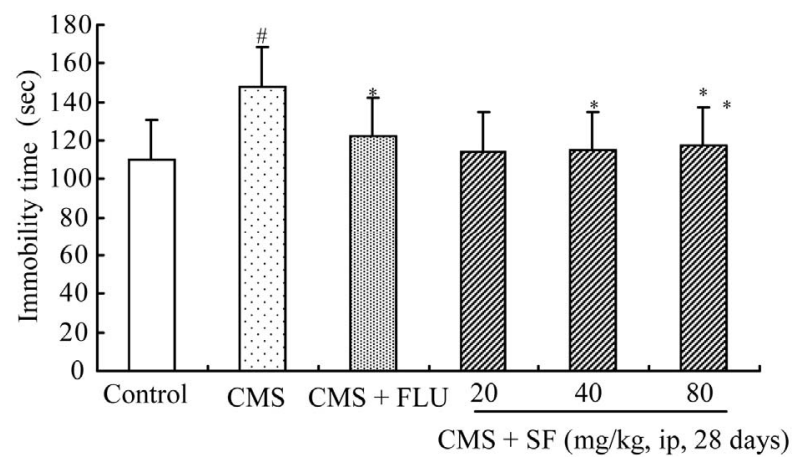

Figure 9. Effect of long-term administration of SF on theimmobility time during the forced-swim test in CMS rats. The rats exposed to CMS and received SF (20 - 80 $\mathrm{mg} / \mathrm{kg}$, ip, once-daily) for 28 days were subjected forced-swimming test, and the measurement of immobility time was carried out by observing the motoric activity of the rats as described in "Materials and methods". The final administration of SF was given $24 \mathrm{~h}$ prior to testing. Values are expressed as the means \pm SEM of 11 animals per group. Data were analyzed with SPSS 10.0 software. $\# P<0.05$ vs. control; *P $<0.05$ vs. CMS.

\section{Discussion}

The result of in vitro tests showed that $\mathrm{SF}$ can protect PC12 cells from the apoptosis induced by $\mathrm{H}_{2} \mathrm{O}_{2}$ and DXM. The results of in vivo tests reveal that acute administration of SF significantly decrease the duration of immobility during forced-swimming test and tail-suspension test, suggesting that SF has an acute antidepressant-like effect. However, SF has no any effects on reserpine-induced hypothermia, 5-hydroxytryptophan-induced head-twitch response, and potentiation of noradrenaline toxicity in mice (data not shown). These experimental facts suggest that the mechanisms of SF antidepressant-like effects are different from those of main kinds of antidepressants that have been employed in the treatment of depression for several decades. Chronic administration of SF reverses the effects of CMS on consumption of food and sucrose solution, weight gain, and histopathology of hippocampus, and significantly shortens the immobility time during forced-swimming test following CMS in rats, suggesting that SF has a chronic antidepressant-like effect. The present behavioral and histopathological data demonstrate that acute administration of SF (also FLU) exhibits a rapid onset of antidepressant effects during forced-swimming and tailsuspension tests, and that chronic administration of SF (20-80 mg/kg, ip, for 28 days ) (also FLU) shows a gradual onset of action. A notable fact is that chronic administration of SF decreases rat aggression (data not shown), this contrasts sharply with the common ability of chronic antidepressive treatment to increase rodent aggression.

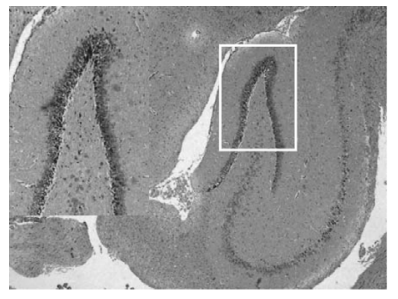

(a)

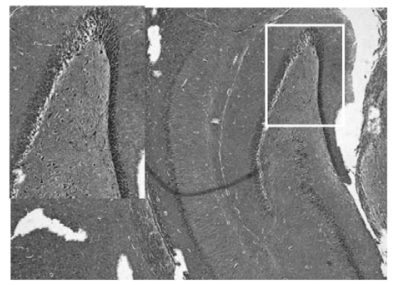

(c)

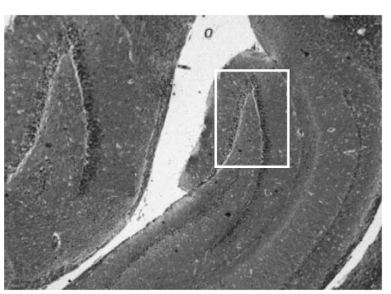

(e)

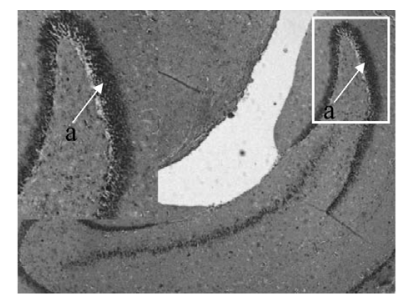

(b)

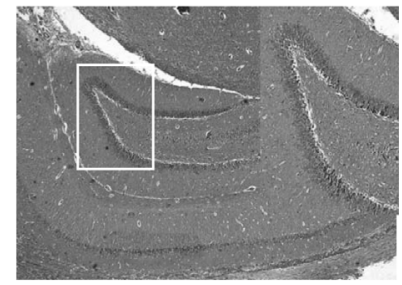

(d)

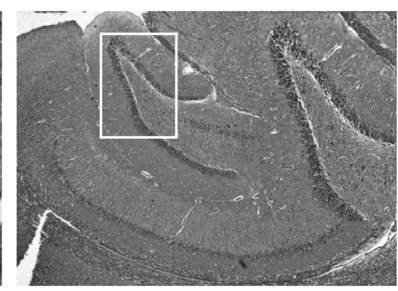

(f)
Figure. 10 Sections through hippocampal regions of CMS rats showing morphorlogical effects of chronic administration of SF. (a). Control, $\times$ 50; (b). CMS, $\times 50$; (c). CMS + FLU $(2.0 \mathrm{mg} / \mathrm{kg}), \times 50 ;($ d). CMS + SF (20 mg/kg), $\times 50 ;(e)$. CMS + SF (40 mg/kg), × 50; (f). CMS + SF (80 mg/kg), × 50; Arrow a. slight intracellular edema, degeneration and hyperplasia .

The deficiencies in our understanding of the etiology of psychiatric disorders are the major obstacle in creating animal models. The only approach that can be used is to try to reproduce one or more symptoms of that disorder in animals. The CMS model considers the reduction of sucrose intake as a measure indicative of anhedonia, which is one symptom of depression. The forced-swimming test as antidepressant screening test relies on acute response to drug treatment. The CMS plus forcedswimming animal model of depression used in the present study may be better able to mimic aspects of the clinical situation of human depression, therefore, may be better used as screening tests for elucidating antidepressant activity.

From what has been discussed above, we may safely draw the conclusion that acute and chronic exposure to SF has an antidepressant-like effect that may involve its neuroprotective actions. Our views to deal with the problem of mechanisms of antidepressant-like effects of $\mathrm{SF}$ are as follows. To begin with, SF (or FA), as a conformationally constrained Glu analogue, may be a competitive antagonist at the Glu receptor [15], and thus in- 
hibits the uptake of Glu in brain and Glu-induced $\left[\mathrm{Ca}^{2+}\right] \mathrm{i}$ through receptor operated $\mathrm{Ca}^{2+}$ channel [30]. $\mathrm{H}_{2} \mathrm{O}_{2}$, one of the main reactive oxygen species, is known to cause lipid peroxidation and DNA damage in cells [31]. Although the specific cause of depression remains unknown, recent studies have provided evidence that oxidative stress plays a role in the pathogenesis of the disease [32,33]. Next, SF (or FA), therefore, as a free radical scavenger, may reduce production of ROSs. These two events strictly interconnected eventually result in reversal of Glu-induced neurotoxicity. In fact, long-term administration of FA per se induces transient activation of astrocytes in hippocampus [10]. Astrocytes are source of various neurotrophic factors, therefore, activation of astrocytes with accompanying expression of neurotrophic factors was postulated to be responsible for brain repair [34,35]. The results obtained from the present study also demonstrate that chronic administration of SF reverses the effect of CMS on histopathology of hippocampus. Preclinical and clinical investigations have shown the involvement of dysregulation of hypothalamic-pituitary-adrenal (HPA) axis in the pathogenesis of depression. Hypercortisolemia and the associated hippocampal atrophy were observed in patients with depression, which could be ameliorated by the treatment with antidepressants [36]. And last, therefore, SF (or FA) may act by mitigating the DXM-induced neurotoxicity.

Last but not least, it should be mentioned that there are some limitations of our study. Firstly, the dose-dependency between $20 \mathrm{mg} / \mathrm{kg}$ and $80 \mathrm{mg} / \mathrm{kg}$ of SF is not clear, indicating that it should be explored for doses lower than $20 \mathrm{mg} / \mathrm{kg}$ of SF. Evidencing of an efficacy for doses lower than $20 \mathrm{mg} / \mathrm{kg}$ would reinforce the interest for such a drug, even if acutely its effect on forced swimming or tail suspension tests appears only from $20 \mathrm{mg} / \mathrm{kg}$. Secondly, effect of ig administration of SF on depression should be assayed, because oral intake of drugs is more common and convenient. Thirdly, the side effects of SF should be further investigated, even though no obvious side effect was detectcted. Finally, an important point to be stressed is that the neuroprotective effects of SF are not sufficient to explain the mechanisms of antidepressive-like effect of SF. Recent studies suggest that increased cell proliferation and increased neuronal number may be a mechanism by which antidepressant treatment overcomes the stress-induced atrophy and loss of hippocampal neurons and may contribute to the therapeutic actions of antidepressant treatment [37]. Therefore, a study on pontential neurogenesis-enchancing action of $\mathrm{SF}$ is now in progress in our laboratory.

\section{Acknowledgements}

The authors would like to thank Dr. Depu Yu for his great encouragement and continuous promotion.

\section{References}

[1] Y. B. Ji, "Pharmacological Action and Application of Blood-Activating and Stasis-Eliminating Available Composition of Traditional Chinese Medicine," Heilongjiang Science and Technique Press, Harbin, 1999, pp. 118-121.

[2] H. Jing, L. Y. Yao, J. S. Li, Y. Q. Song and W. Chao, "Research Progress of Pharmacology of Sodium Ferulate," Northwest Pharmaceutical Journal, Vol. 17, No. 5, 2002, pp. 236-238.

[3] E. Grafe, "Antioxidant Potential of Ferulic Acid," Free Radical Biology and Medicine, Vol. 13, No. 4, 1992, pp. 435-448. doi:10.1016/0891-5849(92)90184-I

[4] B. C. Scott, J. Butler, B. Halliwell and O. I. Aruoma, "Evaluation of the Antioxidant Actions of Ferulic Acid and Catechins," Free Radical Research Communications, Vol. 19, No. 4, 1993, pp. 241-253. doi:10.3109/10715769309056512

[5] M. A. Fernandez, M. T. Saenz and M. D. Garcia, "Antiinflammatory Activity in Rats and Mice of Phenolic Acids Isolated from Scrophularia Frutescens," Journal of Pharmacy and Pharmacology, Vol. 50, No. 10, 1998, pp. 1183-1186. doi:10.1111/j.2042-7158.1998.tb03332.x

[6] Y. Ozaki, “Antiinflammatory Effect of Tetramethylpyrazine and Ferulic Acid," Chemical and Pharmaceutical Bulletin, Vol. 40, No. 4, 1992, pp. 954-956.

[7] A. Suzuki, D. Kagawa, R. Ochiai, I. Tokimitsu and I. Saito, "Green Coffee Bean Extract and Its Metabolites have a Hypotensive Effect in Spontaneously Hypertensive Rats," Hypertension Research, Vol. 25, No. 1, 2002, pp. 99-107. doi:10.1291/hypres.25.99

[8] A. Suzuki, D. Kagawa, A. Fujii, R. Ochiai, I. Tokimitsu and I. Saito, "Short- and Long-Term Effects of Ferulic Acid on Blood Pressure in Spontaneously Hypertensive Rats," American Journal of Hypertension, Vol. 15, No. 4, 2002, pp. 351-357. doi:10.1016/S0895-7061(01)02337-8

[9] J. Zhang, Q. Z. Jin and X. G. Wang, "Research Progresses on Synthesis and Pharmacological Activities of Ferulic Acid and Its Derivatives," Grain and Oil, Vol. 13, No. 1, 2007, pp. 43-45.

[10] J. J. Yan, J. Y. Cho, H. S. Kim, K. L. Kim, J. S. Jung, S. O. Huh, H. W. Suh, Y. H. Kim and D. K. Song, "Protection against Beta-Amyloid Peptide Toxicity in vivo with Long-Term Administration of Ferulic Acid," British Journal of Pharmacology, Vol. 133, No. 1, 2001, pp. 89-96.

[11] Y. P. Zhang, R. D. Ma and L. J. Yu, "Sedative and Hypnotic Effect of Sodium Ferulate in Mice," Nei Mongol Journal of Traditional Chinese Medicine, Vol. 27, No. 7, 2008, pp. 9-11.

[12] S. Z. Li, "Compendium of Materia Medica," (reprinted from 1590 Jinling wood-engraved edition), People's Health Press, Beijing, 2004, pp. 683-686.

[13] Jiangsu College of New Medicine, "Dictionary of Traditional Chinese and Herbal Medicine," Shanghai Science and Technology Publishing House, Shanghai, 1986, pp. 220-222.

[14] T. X. Yu., Y. Zhao, W. C. Shi, R. D. Ma and L. J. Yu, 
"Effects of Maternal Oral Administration of Monosodium Glutamate at a Late Stage of Pregnancy on Developing Mouse Fetal Brain," Brain Research, Vol. 747, No. 2, 1997, pp. 195-206. doi:10.1016/S0006-8993(96)01181-X

[15] L. J. Yu, Y. P. Zhang, R. D. Ma, L. Bao, J. Z. Fang and T. $\mathrm{X}$. Yu, "Potent Protection of Ferulic Acid against Excitotoxic Effects of Maternal Intragastric Administration of Monosodium Glutamate at a Late Stage of Pregnancy on Developing Mouse Fetal Brain," European Neuropsychopharmacology, Vol. 16, No. 3, 2006, pp. 170-177.

[16] Y. P. Zhang, L. J. Yu, R. D. Ma, L. Bao, R. Zeng, J. Z. Fang, X. Y. Zhang and T. X. Yu, "Potent Protective Effect of Ferulic Acid on Glutamat-Induced Neurotoxicity in Adult Mice," Chinese Journal of Neuromedicine, Vol. 7, No. 6, 2008, pp. 596-599.

[17] T. J. Shafer and W. D. Atchison, "Methylmercury Blocks $\mathrm{N}$ - and L-Type $\mathrm{Ca}++$ Channels in Nerve Growth Factor-Differentiated Pheochromocytoma (PC12) Cells," Journal of Pharmacology and Experimental Therapeutics, Vol. 258, No. 1, 1991, pp. 149-157.

[18] M. Yoshizumi, T. Kogame and Y. Suzaki, "Ebselen Attenuates Oxidative Stress-Induced Apoptosis via the Inhibition of the c-Jun N-Terminal Kinase and Activator Protein-1 Signalling Pathway in PC12 Cells," British Journal of Pharmacology, Vol. 136, No. 2, 2002, pp. 1023-1032. doi:10.1038/sj.bjp.0704808

[19] M. B. Hansen, S. E. Nielsen and K. Berq, "Re-examination and Further Development of a Precise and Rapid Dye Method for Measuring Cell Growth/Cell Kill," Journal of Immunological Methods, Vol. 119, No. 2, 1989, pp. 203-210. doi:10.1016/0022-1759(89)90397-9

[20] V. Chigancas, E. N. Miyaji, A. R. Muotri, J. de Fatima Jacysyn, G. P. Amarante-Mendes, A. Yasui and C. F. Menck, "Photorepair Prevents Ultraviolet-induced Apoptosis in Human Cells Expressing the Marsupial Photolyase Gene," Cancer Research, Vol. 60, No. 2, 2000, pp. 2458-2463.

[21] K. Taghzouti, S. Lamarque, M. Kharouby and H. Simon, "Interindividual Differences in Active and Passive Behaviors in the Forced-Swimming Test: Implications for Animal Models of Psychopathology," Biological Psychiatry, Vol. 45, No. 6, 1999, pp. 750-758.

[22] R. D. Porsolt, A. Bertin and M. Jalfre, "Behaviour Despair Models in Mice: A Primary Screening Test for Antidepressants," Archives Internationales de Pharmacodynamie et de Thérapie, Vol. 229, No. 2, 1977, pp. 327-336.

[23] R. D. Porsolt, M. Lepichon and M. Jalfre, "Depression: A New Animal Model Sensitive to Antidepressant Treatments," Nature, Vol. 266, No. 21, 1977, pp. 730-732. doi:10.1038/266730a0

[24] R. D. Porsolt, G. Anton and N. Blavet, "Behaviour Despair in Rats: A New Model Sensitive to Antidepressant Treatments," European Journal of Pharmacology, Vol. 47, No. 4, 1978, pp. 379-391. doi:10.1016/0014-2999(78)90118-8

[25] R. D. Porsolt, "Animal Models of Depression: Utinity for Transgenic Research," Reviews in the Neurosciences, Vol. 11, No. 1, 2000, pp. 53-58.
[26] J. M. Vaugeois, G. Passera, F. Zuccaro and J. Costentin, "Individual Differences in Response to Imipramine in the Tail Mouse Suspension Test," Psychopharmacology, Vol. 134, No. 4, 1997, pp. 387-391.

[27] P. Willner, A. Towell, D. Sampson, S. Sophokleous and R. Muscat, "Reduction of Sucrose Preference by Chronic Unpredictable Mild Stress, and Its Restoration by a Tricyclic Antidepressant," Psychopharmacology, Vol. 93, No. 3, 1987, pp. 358-364.

[28] J. L. Moreau, F. Jenck, J. R. Martin, P. Mortas and W. E. Aefely, "Antidepressant Treatment Prevents Chronic Unpredictabl Mild Stress-Induced Anhedonia as Assessed by Ventral Tegmentum Self-Stimulation Behavior in Rats," European Neuropsychopharmacology, Vol. 2, No. 1, 1992, pp. 43-49. doi:10.1016/0924-977X(92)90035-7

[29] K. T. Hallam, J. E. Horgan, C. McGrath and T. R. Norman, "An Investigation of the Effect of Tacrine and Physostigmine on Spatial Working Memory Deficits in the Olfactory Bulbectomised Rat," Behavioural Brain Research, Vol. 153, No. 2, 2004, pp. 481-486. doi:10.1016/j.bbr.2004.01.005

[30] J. J. Zhang, A. Q. Chen, Y. Z. Gao, H. X. Liu and Y. Zhou, "Effect of Sodium Ferulate on Free Intracellular Calcium in Cortical Neuronal Cultures," Chinese Journal of Clinical Neurosciences, Vol. 10, No. 4, 2002, pp. 342-344.

[31] B. Halliwell and O. I. Aruoma, "DNA Damage by Oxygen-Derived Species. Its Mechanism and Measurement in Mammalian Systems," FEBS Letters, Vol. 281, No. 1-2, 1991, pp. 9-19. doi:10.1016/0014-5793(91)80347-6

[32] G. Lucca, C. M. Comim, S. S. Valvassori, G. Z. Réus, F. Vuolo, F. Petronilho, F. Dal-Pizzol, E. C. Gavioli and J. Quevedo, "Effects of Chronic Mild Stress on the Oxidative Parameters in the Rat Brain," Neurochemistry International, Vol. 54, No. 5-6, 2009, pp. 358-362. doi:10.1016/j.neuint.2009.01.001

[33] Y. C. Wei, F. L. Zhou, D. L. He, J. R. Bai, L. Y. Hui, X. Y. Wang and K. J. Nan, "The Level of Oxidative Stress and the Expression of Genes Involved in DNA-Damage Signaling Pathways in Depressive Patients with Colorectal Carcinoma," Journal of Psychosomatic Research, Vol. 66, No. 3, 2009, pp. 259-266. doi:10.1016/j.jpsychores.2008.09.001

[34] H. Kato, K. Kogure, T. Araki and Y. Itoyama, “Astroglial and Microglial Reactions in the Gerbil Hippocampus with Induced Ischemic Tolerance," Brain Research, Vol. 664, No. 1994, pp. 69-76.

[35] N. Kawahara, C. A. Ruetzler, G. Mies and I. Klatzo, "Cortical Spreading Depression Increases Protein Synthesis and Upregulates Basic Fibroblast Growth Factor," Experimental Neurology, Vol. 158, No. 1, 1999, pp. 27-36.

[36] PGIS, “Global Terrorism Database 1998-2004. GTD2, Codebook, Draft 1.0," Pinkerton Global Intelligence Services (PGIS), Washington DC, 2007.

[37] J. E. Malberg, A. J. Eisch, E. J. Nestler and R. S. Duman, "Chronic Antidepressant Treatment Increases Neurogenesis in Adult Rat Hippocampus," Journal of Neuroscience, Vol. 20, No. 24, 2009, pp. 9104-9110. 